\title{
The Effect of Migration on Inequality: Case of Albania
}

\section{Güngör Turan}

Ph.D, Department of Economics, Epoka University, Tirana, Albania, gturan@epoka.edu.al

\section{Jerina Podo}

Master student at Banking and Finance Department, Epoka University, Tirana Albania, jpodo@epoka.edu.al

\section{Doi:10.5901/ajis.2014.v3n3p314}

\begin{abstract}
The aim of this paper is to provide the effect of migration on inequality by generating the empirical evidence on the relationship between international remittances and income inequality. It has also been analyzed whether the socio-economic and political factors affect the internal and external migration as Albania is a country on internal and internationally move. Focusing on the external migration there are done some studies on which are the main countries of Albanian migration and the role of the remittances on inequality with regard to per capita income. As more than half of the Albanian population has direct exposure to migration phenomena, this examination aims to evaluate the level of the effect of remittances on the income inequality during 1992-2012 period. The estimated model will be offered by all fundamentals of regression analyze which will define the relation between the remittances (in \% of GDP) and the income inequality. Remittances refer to official worker remittances flows, representing only money sent through official banking channels. After reasonable analysis it was argued that there is a weak correlation between remittances and income inequality as the main reasons of income inequality are other social, economic and political factors.
\end{abstract}

Keywords: Migration, Income Inequality, Remittances

\section{Introduction}

After the Communism regime, starting from 1990, a great migratory movement has been started as dominating fact in Albania which generated that one decade later, almost every family to had at least one family member abroad, mainly in Greece and in Italy. This phenomena made remittances the most important source of foreign exchange by constituting 14 $\%$ of GDP (IMF, 2002). Migration, with regard to remittances and income inequality, as very tight related factors, has always been discussed and studied by different economic and finance researchers and academicians as inequality is an indicator of poverty and for this reason it is a challenge to reduce it.

This paper consists in a general overview on the developing countries by focusing in Albanian migration history and also on the effect of the remittances of money and goods by migrants to their country of origin on the distribution of income and welfare in between households as in developing economies the earnings are low and the migration provides the most important source of income for other family members. At the same time, this study provides two types of categorizations, based on the country where the remittances come from and based on the usage of them. The main countries where the majority of Albanian people have migrate in the last two decades are Greece and Italy, but also smaller number of people have been distributed in other different countries of Europe such as United Kingdom, Germany etc, but also a considerable number of people have migrated in USA, Canada and Australia. The main purposes of usage of remittances are: (a) to support basic daily needs (food, clothing etc), (b) to improve living conditions (home equipment, furniture etc), (c) to expand or build a new house, (d) deposit in bank accounts, (e) save cash at home and only few of them are used for investment. Although this thesis focuses more on how all the above mention factors as a result of international remittances can cause an unequal income distribution.

In addition, this study provides some evidences on the impact of the financial crises on the flow of remittances. Even though, Albania is one of the countries which was not highly effected by the crises and its GDP growth kept positive during that period, some of the host countries of Albanian migrants had a decrease in the employment level which directly affected the inflow of remittances in Albania. 


\section{Literature Review}

Out migration, like the adoption of a new production technology, entails costs and risks. The costs and risks are likely to be especially high in the case of international migration. Given this fact, pioneer migrants tend to come from households at the upper-middle or top of the sending-area's income distribution (e.g., Portes and Rumbaut, 1990; Lipton 1980), and the income they send home in the form of remittances is therefore likely to widen income inequalities in migrant-source areas (Stark, Taylor and Yitzhaki 1986) cent empirical work (Stark et al., 1986; Stark,

Nowadays, migration and remittances is mostly believed to be a rational family decision, otherwise called tempered self-interest or enlightened altruism (Rapoport and Docquier 2005:47). The motives naturally depend on individual characteristics, which can be categorized into five components: demographic, cultural, economic, migratory and macroeconomic components (Salomone 2006:10)

Inequality is often regarded as a necessary evil which has to be tolerated to allow growth, "it has been argued that inequality is necessary for accumulation, and that it therefore contains the seeds of eventual increases in everyone's income (Adelman and Robinson, 1989). 98

The simpliest way to investigate the remittances effect on inter-households income distribution consists in considering these flows as an exogenous source of income that simply adds to the households' current income. It consists often in breaking down the Gini coefficient according to the influence that every source of income has respectively upon this coefficient (Lerman and Yitzhaki, 1985).8; Ta

. International migration has been an historical constant for Albanians starting from the mass out-migration of the 15th century following the death of Scanderbeg - Albania's national hero, and the ensuing invasion of the country by the Ottomans. 200,000 Albanians or one-quarter of the country's then total population migrated within a short period of time (1468-1506), primarily in the direction of Italy, Greece and the Dalmatian Coast (Tirta, 1999; Çaro, 2011).

Since 1991, Albania has experienced a massive flow of international migration and a huge internal movement of the population. Between 1991 and 1992, it is estimated that 300,000 Albanians left the country. By the mid-1990s, the estimated figure of emigrants abroad was around 400,000 of whom almost 90 percent were in Greece (Danaj and Ekonomi, 2004).

\section{Migration History in Developing Countries}

Migration is a phenomena that has started a long time ago and has become an important factor in shaping the economical and social indicators in implicated countries. It provides big changes in the growth and development of both home and host countries. The society has accepted migration also as part of globalization.

According to different empirical studies the most developed countries in the world such as Europe and North America host the large number of migrants, next is Asia with almost the same amount of migrants and the countries with the lower amount of migrants are the developing countries. In developing countries there are evidences that show that even though they host the lower amount of migrants, they have high outflows of people who migrate in developed countries.

\subsection{A Brief Overview on Migration and Inequality Indicators}

The majority of the people who live in countries with low standards of living evaluate migration as the best solution for their situation even if it is difficult. Migration has a great impact also in the social and psychological situation of the person, as moving from one country to another makes the people face the movement from one culture to another, which refers to different social environment.

\subsection{Migration Indicators}

One of the main reasons of migration is poverty, which is mostly evident to those who migrate from developing countries to developed countries. This type of migration can provide also the illegal migration which generates problems for government and board authorities. The illegal migration makes government compile more restricted migration policies.

The next reason that makes people migrate is the economic conditions, such as moving from one country with less development in industry to a country with high level of industry development. The indicators of migration there are a lot, it can be for health issues, studying, political freedom, religion freedom, labour demand, etc. 


\subsection{Inequality Indicators}

While, income inequality refers to the way how the income and wealth is distributed among people or among country. The factors that impact the income inequality are a lot, which include gender inequality, technological changes, labour market outcomes and globalization which is tightly connected to migration. Income distribution plays a role also in the long run growth of the country.

\subsection{Main Characteristics of Albanian Migration}

During the Communism Regime the Albanian people had very limited opportunities to migrate and move outside the borders. This generated that after the communism, in 1990, Albania had a high flow of people toward other countries. The most preferred destinations were Greece, Italy, Germany and United States of America. The migration of Albanian population was mostly due to high level of poverty and very low standards of living, which was later followed by various economic, social and political factors. The high level of unemployment, low standards of living, unstable political situation, stimulated the desire of Albanian people to migrate, mostly illegal.

\subsection{Magnitude of Remittances in Albania}

The majority of Albanian people migrated without the family, generally only the household moved to another country and provided financial support for the other members of the family. This situation increased the inflow of remittances in Albania, especially in the middle of 1996, as for most of the families the only source of money was the remittances sent by the familiars abroad. The support submitted by the migrants to their family members was not only in cash, but also in clothes and food. The inflow of the remittances in Albania, decreased a lot in 2008, due to financial crises. The global financial crises affected mostly the economy of Greece, which generated a huge decrease in the remittances coming from Greece, where is located the majority of the migration population of Albania. Another factor that had an impact in the decrease of the remittances in Albania was also because the persons who migrated, took also the other members of the family in that country, which refers to less money sent in Albania.

\section{Data and Methodology}

\subsection{Simple Regression Analysis}

Regression Analysis describes the relationship between one variable that is going to be predicted based on an independent variable, by using statistical methods that generate an equation.

Multiple $\mathrm{R}$ shows the correlation between $\mathrm{y}$ and $\mathrm{x}$, which is 0,68 or $68 \%$. While the value of $\mathrm{R}$ square is 0.46 or $46 \%$, which means that only $46 \%$ of correlation can be explained.

The standard error is high which indicates that the data points are spread out over a large range of values.

The number of observations in this regression is 21.

TSS (Total sum of squares) $=$ ESS (error sum of squares) + RSS (Regression sum of squares)

$\mathrm{R}^{2}$ refers to the ratio of the explained sum of squares to the total sum of squares, which is practically the fraction of the variation of dependent variable that is predicted by the independent variables

R-squared = Explained Sum of Squares $/$ Total Sum of Squares

$\mathrm{R}^{2}=\mathrm{ESS} / \mathrm{TSS}$

$\mathrm{R}^{2}=1-\mathrm{RSS} / \mathrm{TSS}$

$R^{2}=1-70.1633937850464 / 130.997923809524=1-0.5356069145574144=0.464$

So $46 \%$, which yields the R-square given in the regression Statistic table

$0<R^{2}<1$

0 -means that the model did not explain any of the variation in the dependent variable.

1-means that the model explained everything.

0.46 is a value in between 0 and 1 which means that is a good result (well explained).

The regression model is: $y=ß 1+\beta 2 x+u$

b1 $=27.4$

b2 $=0.004$

$y=27.4+0.004 x$ 
Inequality (Gini coefficient) $=27.4+0.004$ remittances

The slope coefficient has the estimated standard error 0.88 , which shows the average distance that the observed values fall from the regression line

The slope coefficient has t-statistic of $27.4120654065034 / 0.889337903462534=30.8$, which is the coefficient divided by its standard error

The $p$-value is determined by the t-statistic and t-distribution. In this case the slope coefficient has $p$-value of 1.09

The 95\% confidence interval for $ß_{2}(0.00197,0.00618)$

4.2 An examination of the relationship between inequality (gini coefficient) and remittances: non-stationary time series data and Johansen Co-integration Test

Time series data refers to study of data collected through time which are necessary for providing pure research and practical implementation. Such usage has resulted in considerable misunderstanding because, in reality, stationary and non stationary are essentially indistinguishable except where changes in an underlying process are so dramatic that no statistical assessment is necessary (Koutsoyiannis, 2011a)

The data are annual and consist in yearly Gini coefficient obtained by World Bank and indexmundi (www.worldbank.org, www.indexmundi.com/, accessed: March 26, 2014) and total remittances sent in Albania in USD are taken from Bank of Albania, IMF (www.bankofalbania.org, www.imf.org, accessed: March 05, 2014) The sample period is from 1992 to 2012. All tests are conducted by using E Views statistical program.

Graph 1: Total of remittances sent in Albania(in mil. USD), 1992-2012

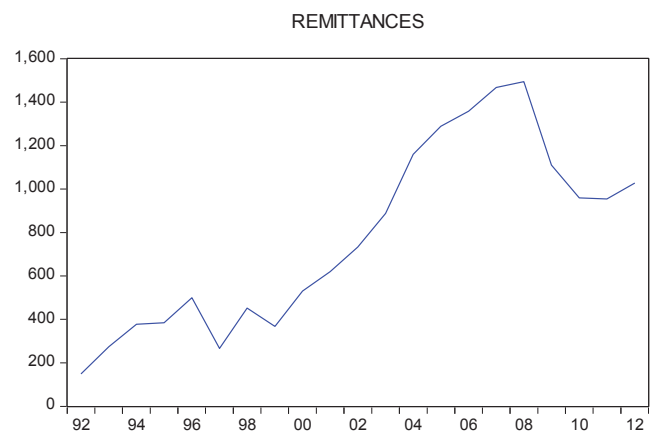

By observing the graph it is easily remarkable that the highest amount of total of remittances sent in Albania has been arised in 2007, and there are a lot of ups and downs, but they have started to decrease evidently after 2008 due to financial crises.

Graph 2: Gini coefficient in Albania, 1992-2012

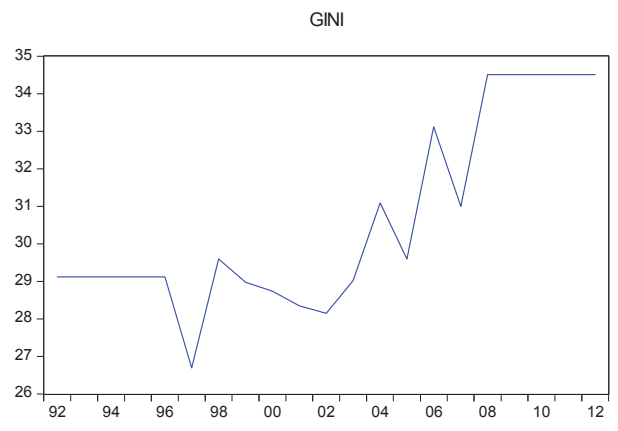


As it can be noticed by the graph Gini coefficient in Albania has been unstable during the years. From the values it can be observed that it never reaches the value 0, which means perfect income distribution equality, but it has been low in 1997 and after that it has started to increase continuously, which means higher inequality through the years.

Graph 3: Total remittances and Gini coefficient in Albania, 1992-2012, scatter diagram

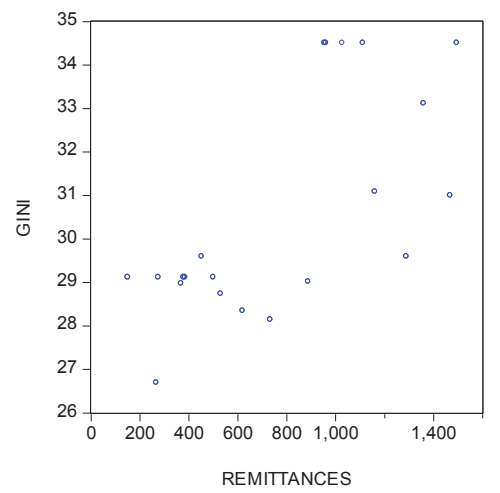

The highest value of the total remittances and Gini coefficient in the scatter diagram above corresponds to 2008 when the Gini coefficient was 34.51 and total remittances value was 1495 (in mil. USD). This shows that there is a relationship between these two variables. According to the scatter diagram moving to the right: as remittances decrease, Gini coefficient has a decreasing trend and remittances increases, Gini coefficient increases as well. In a certain point seems that both remittances and Gini coefficient become constant while the correlation stabilizes.

Graph 4: Histogram and statistics of total remittances sent in Albania(in mil. USD)

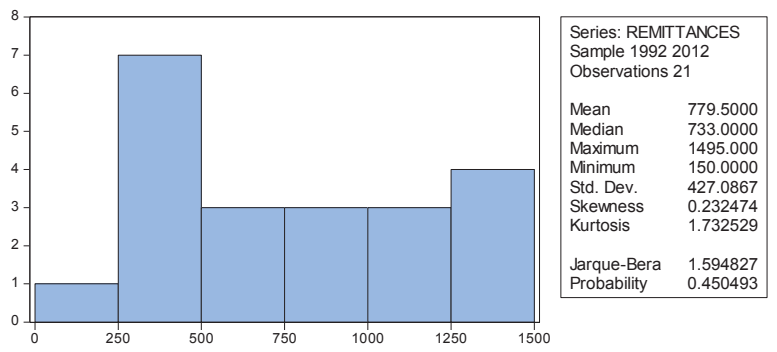

This sample has an average in between the interval of 25.550 and 29.273 , which indicates the value 27.411 in the Confidence Interval of $95 \%$ which means that it is $95 \%$ confidence that the true average of the process is in between these two values.

Graph 5: Histogram and statistics of Gini coefficient series

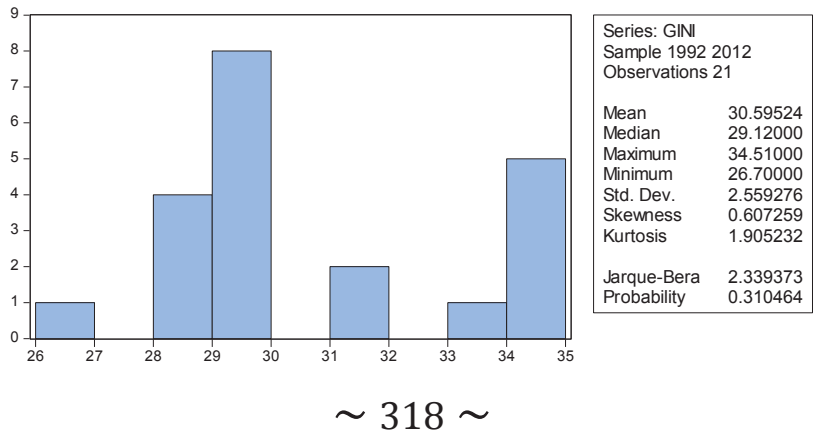


Table 1: Descriptive statistics of total remittances and Gini coefficient series

\begin{tabular}{|lcc|}
\hline & REMITTANCES & GINI \\
Mean & 779.5000 & 30.59524 \\
Median & 733.0000 & 29.12000 \\
Maximum & 1495.000 & 34.51000 \\
Minimum & 150.0000 & 26.70000 \\
Std. Dev. & 427.0867 & 2.559276 \\
Skewness & 0.232474 & 0.607259 \\
Kurtosis & 1.732529 & 1.905232 \\
& & \\
Jarque-Bera & 1.594827 & 2.339373 \\
Probability & 0.450493 & 0.310464 \\
Sum & 16369.50 & 642.5000 \\
Sum Sq. Dev. & 3648060. & 130.9979 \\
Observations & 21 & \\
\hline
\end{tabular}

Mean refers to the average across the observations.

Minimum is the lower value of the variable and Maximum stands for the higher value of the variable.

The Standard Deviation serves for measuring the spread of observations, which is very high for remittances.

While Skewness value should be near to 0 and measures the direction and the degree of symmetry. This means that the symmetry of the remittances and Gini coefficient is less symmetric than remittances but both variables has good values with regard to Skewness.

Kurtosis is a statistical measure that shows the distribution of the observed data around the mean and trends in charts. A high value of kurtosis means fat tails while a low value of kurtosis refers to skinny tails. The values of kurtosis for remittances and Gini coefficient are positive and are near to the expected value 3, which is the value where there are "well behaved" tails and there is normal distribution.

Table 2: Estimation equation output of regresssion

Dependent Variable: GINI

Method: Least Squares

Date: 05/12/14 Time: 13:46

Sample: 19922012

Included observations: 21

\begin{tabular}{|c|c|c|c|c|}
\hline Variable & Coefficient & Std. Error & t-Statistic & Prob. \\
\hline REMITTANCES & 0.031431 & 0.003302 & 9.518133 & 0.0000 \\
\hline R-squared & -26.317575 & Mean dependent var & & 30.59524 \\
\hline Adjusted R-squared & -26.317575 & S.D. dependent var & & 2.559276 \\
\hline S.E. of regression & 13.37637 & Akaike info criterion & & 8.071304 \\
\hline Sum squared resid & 3578.546 & Schwarz criterion & & 8.121044 \\
\hline Log likelihood & -83.74870 & Hannan-Quinn criter. & & 8.082099 \\
\hline Durbin-Watson stat & 0.120168 & & & \\
\hline
\end{tabular}

The test of sationarity check of the time series is prerequisite for the cointegration analysis. A time series that have time invariant mean, variance and covariance is called stationary time series. Unit root test serves as a pre-test to avoid spurious regression results (Granger, 1986). The worker's remittances increase the growth of the recipient economy as it reduces the current account deficit of the economy. Inflows of worker's remittances also help to reduce the external borrowing and thus reduce the external debt burden. Worker's remittances improve the foreign exchange position as it is 
an important source of foreign exchange inflows. Its role in the improvement of the balance of payment and reduction in external dependence has positive impacts on the economy. There are some evidences that the remitted foreign exchange is also used as "productive investment". The inflow of worker's remittances is concluded to be third important source of the capital for the growth of an economy. (Iqbal and Sattar, 2005).

The Johansen Fisher panel cointegration test aggregates the $p$ values of individual Johansen maximum eigenvalues and trace statistics. The value of the chi-square statistic is based on the Mackinnon et al. (2001) p-values for cointegration trace test and maximum eigenvalue test. The result indicates one cointegrating vector. (Johansen`s, 1988)

The stationary of each series was investigated by employing the unit root tests developed by Dickey and Fuller. The test consists of regressing each series on its lagged value and lagged difference terms. The number of lagged differences to be included can be determined by the Akaike information criterion (Hill et al., 2008) It is proposed to conduct a panel ADF unit root test based on Fisher (1932). The Fisher ADF test essentially combines the $p$ values of the test statistic for a unit root in each residual cross-sectional unit. The test has a chi-square distribution with 2 degrees of freedom. (Maddala and Wu, 1999)

In Table 3, it is stated the Augmented Dickey-Fuller test statistics on the established null hypothesis of a unit root. As the null hypothesis is of a unit root, the alternative hypothesis is on stationary data so the hypothesis of unit root against the stationary alternative is not rejected at $5 \%$ levels (critical value). Since the calculated ADF test statistic is 0.191 is greater than the $5 \%$ critical value of $(-3.029970)$ it is not rejected the null hypothesis of nonstationary. The results of this test are shown in Table 3.

Table 3: Augmented Dickey-Fuller unit root test statistic on Gini coefficient

Null Hypothesis: GINI has a unit root

Exogenous: Constant

Lag Length: 1 (Fixed)

\begin{tabular}{cccc}
\hline \hline & & t-Statistic & Prob.* $^{*}$ \\
\hline \hline Augmented Dickey-Fuller test statistic & & \\
\hline Test critical values: & 1\% level & 0.191580 & 0.9644 \\
& 5\% level & -3.831511 & \\
& 10\% level & -3.029970 & \\
& & -2.655194 & \\
& & & \\
\hline \hline
\end{tabular}

*MacKinnon (1996) one-sided p-values.

Warning: Probabilities and critical values calculated for 20 observations and may not be accurate for a sample size of 19

Augmented Dickey-Fuller Test Equation

Dependent Variable: $\mathrm{D}(\mathrm{GINI})$

Method: Least Squares

Date: 05/12/14 Time: 13:48

Sample (adjusted): 19942012

Included observations: 19 after adjustments

\begin{tabular}{lcccc}
\hline \hline \multicolumn{1}{c}{ Variable } & Coefficient & Std. Error & t-Statistic & Prob. \\
\hline \hline GINI(-1) & 0.027300 & 0.142500 & 0.191580 & 0.8505 \\
D(GINI(-1)) & -0.652712 & 0.214746 & -3.039456 & 0.0078 \\
C & -0.362902 & 4.326463 & -0.083880 & 0.9342 \\
\hline \hline R-squared & 0.404163 & Mean dependent var & 0.283684 \\
Adjusted R-squared & 0.329684 & S.D. dependent var & 1.663969 \\
S.E. of regression & 1.362339 & Akaike info criterion & 3.600222 \\
Sum squared resid & 29.69546 & Schwarz criterion & 3.749344 \\
Log likelihood & -31.20211 & Hannan-Quinn criter. & 3.625459 \\
F-statistic & 5.426494 & Durbin-Watson stat & \\
Prob(F-statistic) & 0.015886 & & & \\
\hline \hline
\end{tabular}


Another way for evaluating the null hypothesis is of a unit root is through the ADF test is by comparing the $p$-value. If $p$ value is greater than 0.05 there is unit root, in the analysis results it is shown that the $p$-value is 0.9644 , so greater than 0.05 , thus do not reject the the null hypothesis is of a unit root. By observing both ways of analyzing with the result of not rejecting the null hypothesis which is on the unit root, it can be stated that the Gini coefficient series has a unit root.

Table 4: Augmented Dickey-Fuller unit root test statistic on total remittances

Null Hypothesis: REMITTANCES has a unit root

Exogenous: Constant

Lag Length: 1 (Fixed)

\begin{tabular}{cccc}
\hline \hline & & t-Statistic & Prob.* \\
& & & \\
\hline \hline \multicolumn{2}{c}{ Augmented Dickey-Fuller test statistic } & -1.271994 & 0.6200 \\
\hline Test critical values: & 1\% level & -3.831511 & \\
& $5 \%$ level & -3.029970 & \\
& $10 \%$ level & -2.655194 & \\
& & &
\end{tabular}

*MacKinnon (1996) one-sided p-values.

Warning: Probabilities and critical values calculated for 20 observations

and may not be accurate for a sample size of 19

Augmented Dickey-Fuller Test Equation

Dependent Variable: D(REMITTANCES)

Method: Least Squares

Date: 05/12/14 Time: 13:49

Sample (adjusted): 19942012

Included observations: 19 after adjustments

\begin{tabular}{lcccc}
\hline \hline \multicolumn{1}{c}{ Variable } & Coefficient & Std. Error & t-Statistic & Prob. \\
& & & & \\
\hline \hline REMITTANCES(-1) & -0.111894 & 0.087968 & -1.271994 & 0.2216 \\
D(REMITTANCES(-1)) & 0.166885 & 0.233848 & 0.713648 & 0.4857 \\
C & 121.9909 & 79.30921 & 1.538168 & 0.1435 \\
& & & & \\
\hline \hline R-squared & 0.114275 & Mean dependent var & 39.58947 \\
Adjusted R-squared & 0.003559 & S.D. dependent var & 157.1160 \\
S.E. of regression & 156.8362 & Akaike info criterion & 13.09222 \\
Sum squared resid & 393561.5 & Schwarz criterion & 13.24134 \\
Log likelihood & -121.3761 & Hannan-Quinn criter. & 13.11746 \\
F-statistic & 1.032145 & Durbin-Watson stat & 2.084300 \\
Prob(F-statistic) & 0.378785 & & \\
& & & \\
\hline \hline
\end{tabular}

Table 4 show evidently that as calculated ADF t-statistic is (-1.27) so greater than the $5 \%$ critical value of (-3.029970), do not reject te null hypothesis of non stationary. Thus, remittances has a unit root.

Therefore, both variables, Gini coefficient and total remittances have unit root, so it is needed to take into consideration the differences of both variables, because if both independent variable and dependent variable show the presence of unit root, the regression results do not hold much meaning.

Table 5 shows that after taking second difference (lags) of variable of Gini coefficient series, the calculated ADF unit root test (-3.142404) is less than the $5 \%$ critical value (-1.961409) do not reject the null hypothesis of non-stationary. So, Gini coefficient has not a unit root, it is stationary. 
Table 5: Augmented Dickey-Fuller unit root test statistic on D (GINI)

Null Hypothesis: $\mathrm{D}(\mathrm{GINI})$ has a unit root

Exogenous: None

Lag Length: 1 (Fixed)

\begin{tabular}{cccc} 
& & t-Statistic & Prob. $^{*}$ \\
\hline \hline \multicolumn{2}{c}{ Augmented Dickey-Fuller test statistic } & -3.142404 & 0.0036 \\
\hline Test critical values: & 1\% level & -2.699769 & \\
& 5\% level & -1.961409 & \\
& $10 \%$ level & -1.606610 & \\
\hline
\end{tabular}

*MacKinnon (1996) one-sided p-values

Warning: Probabilities and critical values calculated for 20 observations

and may not be accurate for a sample size of 18

Augmented Dickey-Fuller Test Equation

Dependent Variable: $\mathrm{D}(\mathrm{GINI}, 2)$

Method: Least Squares

Date: 05/12/14 Time: 14:01

Sample (adjusted): 19952012

Included observations: 18 after adjustments

\begin{tabular}{llccc}
\hline \hline \multicolumn{1}{c}{ Variable } & Coefficient & Std. Error & t-Statistic & Prob. \\
\hline \multicolumn{1}{c}{$\mathrm{D}(\mathrm{GINI}(-1))$} & -1.388246 & 0.441778 & -3.142404 & 0.0063 \\
\multicolumn{1}{c}{ (GINI(-1),2) } & -0.124689 & 0.248049 & -0.502679 & 0.6220 \\
\hline \hline R-squared & 0.796220 & Mean dependent var & 0.000000 \\
Adjusted R-squared & 0.783484 & S.D. dependent var & 3.095893 \\
S.E. of regression & 1.440560 & Akaike info criterion & 3.672380 \\
Sum squared resid & 33.20341 & Schwarz criterion & 3.771310 \\
Log likelihood & -31.05142 & Hannan-Quinn criter. & 3.686021 \\
Durbin-Watson stat & 2.054513 & & & \\
\hline
\end{tabular}

Table 6: Augmented Dickey-Fuller unit root test statistic on D(REMITTANCES)

Null Hypothesis: D(REMITTANCES) has a unit root

Exogenous: None

Lag Length: 1 (Fixed)

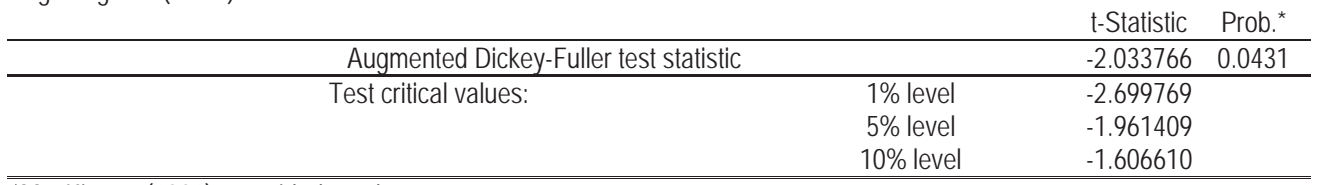

*MacKinnon (1996) one-sided p-values.

Warning: Probabilities and critical values calculated for 20 observations

and may not be accurate for a sample size of 18

Augmented Dickey-Fuller Test Equation

Dependent Variable: D(REMITTANCES,2)

Method: Least Squares

Date: 05/12/14 Time: 14:02

Sample (adjusted): 19952012

Included observations: 18 after adjustments

Variable Coefficient Std. Error t-Statistic Prob.

D(REMITTANCES(-1))

D(REMITTANCES(-1),2)

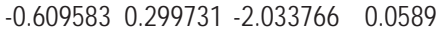

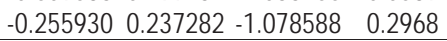

R-squared

Adjusted R-squared

S.E. of regression

Sum squared resid

0.447789 Mean dependent var 1.722222

Log likelihood

0.413275 S.D. dependent var 210.5622

161.2863 Akaike info criterion 13.10868

416212.5 Schwarz criterion 13.20761

Durbin-Watson stat

-115.9781 Hannan-Quinn

13.12232

1.879447 
Table 6 presents, after taking second differences (lags) of variable of remittances and calculating the ADF unit root test statistic vale $(-2.033766)$ lower than the $5 \%$ critical value of $(-1.961409)$, do not reject the null hypothesis of nonstationary. Thus, remittances series has not a unit root, so it is stationary.

By referring to the unit tests as it is stated above, it is conducted the Johansen's co-integration test for evaluating if the combinations of both dependent and independent variables are co integrated.

Table 7: Johansen Co-integrated Test

Date: 05/12/14 Time: 14:10

Sample (adjusted): 19952012

Included observations: 18 after adjustments

Trend assumption: Linear deterministic trend

Series: GINI

Lags interval (in first differences): 1 to 2

Unrestricted Cointegration Rank Test (Trace)

\begin{tabular}{ccccc}
\hline \hline $\begin{array}{c}\text { Hypothesized } \\
\text { No. of CE(s) }\end{array}$ & Eigenvalue & $\begin{array}{c}\text { Trace } \\
\text { Statistic }\end{array}$ & $\begin{array}{c}0.05 \\
\text { Critical Value }\end{array}$ & Prob. $^{* *}$ \\
\hline \hline None & 0.001732 & 0.031196 & 3.841466 & 0.8598 \\
\hline \hline
\end{tabular}

Trace test indicates no cointegration at the 0.05 level

* denotes rejection of the hypothesis at the 0.05 level

**MacKinnon-Haug-Michelis (1999) p-values

Unrestricted Cointegration Rank Test (Maximum Eigenvalue)

\begin{tabular}{|c|c|c|c|c|}
\hline $\begin{array}{l}\text { Hypothesized } \\
\text { No. of CE(s) }\end{array}$ & Eigenvalue & $\begin{array}{l}\text { Max-Eigen } \\
\text { Statistic }\end{array}$ & $\begin{array}{c}0.05 \\
\text { Critical Value }\end{array}$ & Prob.** \\
\hline None & 0.001732 & 0.031196 & 3.841466 & 0.8598 \\
\hline
\end{tabular}

Max-eigenvalue test indicates no cointegration at the 0.05 level

* denotes rejection of the hypothesis at the 0.05 level

**MacKinnon-Haug-Michelis (1999) p-values

Unrestricted Cointegrating Coefficients (normalized by $b^{\prime *}$ S11*b=l):

\begin{tabular}{cc}
\hline \hline $\mathrm{GINI}$ & \\
0.500816 & \\
\hline \hline & Unrestricted Adjustment Coefficients (alpha): \\
\hline \hline $\mathrm{D}(\mathrm{GINI})$ & 0.053305 \\
\hline
\end{tabular}

According to the results shown in Table 7 on the LR test statistics and critical values, it is suggested that there is a co integration relationship between Gini coefficient and total remittances at the $5 \%$ significance level. This means that there is a long run stable relationship between Gini coefficient and total remittances, which shows that Gini coefficient and total remittances move together in the long run in Albania.

\section{Conclusions}

Migration as a phenomena have played an important role in the Albanian economy after 1990. Remittances have been the main source of income for most of the Albanian families, this is clearly noted by the high values of the inflows of remittances during 1992-2012 period. At the same time, during the analysis of this paper has been noticed a strong 
impact of remittances in the government budget, which is clearly showed by the high values of the report Remittances per GDP, which have the peak in 1996 and later has started to decrease in 1997, as Albania faced the civil war during that period and again has continuously decreased after 2007 due to financial crises. The high level of remittances means higher standards of living for Albanian people, which refers to higher income for families.

According to the results of the analysis conducted for 1992-2012 period in Albania by using Johansen Cointegration Test and based on the LR test statistics and critical values, it was concluded that there is a co integration relationship between Gini coefficient and total remittances at the $5 \%$ significance level. This means that there is a long run stable relationship between Gini coefficient and total remittances, which shows that Gini coefficient and total remittances move together in the long run in Albania.

This means that migration has not an effect in the income inequality for the short run, but it has a considerable impact in the long run in Albania, which refers to the fact that remittances and income inequality go monotonically together in the long run.

\section{References}

Adams, Richard H; Page, John (2003), International Migration, Remittances and Poverty in Developing Countries, World Bank Policy Research Working Paper 3179

Aggarwal, Reena; Demirgüç-Kunt, Asli; Soledad Martinez Peria, Maria (2006), Do Workers' Remittances Promote Financial Development?, World Bank Policy Research Working Paper 3957

Albanian Center for Economic Research. 1995 Small Business Survey in Albania, Tirana: ACER.

Chami, Ralph; Fullenkamp, Connel; Jahjah, Samir (2005), Are Immigrant Remittance Flows a Source of Capital for Development, IMF Staff Papers, Vol. 52, No. 1

Gorniak, Jaroslaw; Katsiaouni, Olympios (2001), Globalisation and Rural Poverty in Transition Economies, Paper for Expert Group Meeting organised by Division for Social Policy and Development, United Nations, New York

Gedeshi I. 2002. "Role of Remittances from Albanian Emigrants and Their Influence in the Country's Economy," Eastern European Economics 40(5): 49-72.

INSTAT, (2012), "Census of Housing and Population 2011)", http://www.instat.gov.all, (accessed 22 May 2012)

Mountford, A. (1997): "Can brain drain be good for growth in the source economy?", Journal Development Economics, 53 (2), pp. 287303.

O'Rourke, K.H. (2001): Globalization and Inequality: Historical Trends, Trinity College, Dublin, CEPR and NBER.

Stark, O. and D. Levhari (1982): "On migration and risk in LDCs", Economic Development and Cultural Change, vol 31, n⿳0 1, 191-96.

Trachtman, J.P. (2009): "The international law of economic migration: Towards the fourth freedom", Institute for Employment Research, Michigan, W.E. Upjohn.

World Bank (2007), « Albania: Urban growth, migration and poverty reduction », Report No. 40071- AL, The World Bank, Washington $\mathrm{DC}$ 